\title{
ETHNIC IDENTITY AND ETHNIC CULTURE AMONG THE RESIDENTS OF EASTERN LATVIA
}

\author{
Valērijs Makarevičs \\ Daugavpils University, Latvia \\ Dzintra Iliško \\ Daugavpils University, Latvia
}

\begin{abstract}
Ethnic identity is an important component of a person's personal identity. Many studies indicate that a strong and secure ethnic identity positively correlates with an adequate self-esteem, coping mechanisms, and optimism. In this study the authors intend to analyse the socio-psychological theories of the ethnic group, ethnic identity and the relationship of ethnic identity and ethnic culture. This article reflects findings gained as a result of a comparative analysis of the characteristics of ethnic identity and its connectedness with ethnic culture among the students of Eastern Latvia. The authors identify what is common for the ethnic groups of the region, as well as point to the differences in the perceptions of their ethnic identity and its manifestation among the respondents. Research methodology: The authors developed a methodology that combines quantitative and qualitative methods of processing the results. This article reflects part of the data obtained as a result of conducting inquiry, where respondents were asked to name literary works in which their ethnic character is reflected most vividly, as well as to name traditions that corresponds to their ethnic identity. The results of the study suggest that there is an idea of the ideal ethnic character and its manifestation. The ethnic traditions, mentioned by the respondents who has Latvian as their native language, were associated with nature, cyclical rhythms in nature and religious symbols. As for the respondents who had Russian as their mother tongue, the most significant were such public holidays such as the New Year, as well as traditional religious festivals.
\end{abstract}

Keywords: ethnic identity, ethnic culture, ethnic character, Eastern Latvia.

\section{Introduction}

The focus of current study is the ethnic self-identification of the research participants and its relatedness to ethnic culture among both Latvian and Russian speaking pool students of Eastern Latvia where the students are situated in the multicultural environment. The aim of the research is to analyse the sociopsychological theories of the ethnic group, ethnic identity and the relationship of ethnic identity and ethnic culture as a background for a more detailed exploration of the characteristics of ethnic identity and its connectedness with ethnic culture among the residents of the Eastern Latvia. 
The research method employed in this study is the analyses of the data gained in the survey conducted among the University students on how literary works and festivals that best describe their ethnic identity as well as their ethnic character and its manifestation. The authors try to identify the common features that unite ethnic groups of the region and point to the differences in the perceptions of their ethnic identity and their manifestation among respondents. The language spoken is one of the many manifestations of ethnic identity. To obtain a holistic picture, there is a need to a in-depth exploration of other indicators of ethic identity as well.

As Phinney notes, ethnic identity plays a central role in the psychological functioning of members of ethnic and racial minorities, but research on this topic is fragmented and inconclusive. (Phinney, 1990). The socio-demographic processes that are taking place in Old Europe and the North American continent lead to an increase in the number of interethnic conflicts. On the other hand, the idea that the division of people into ethnic groups may hinder further development of a globalized economy sometimes is reflected in the works of many scientists (Blanton, 2015). Of course, ethnic identity is manifested in the certain requirements set by the ethnic culture. Therefore, in this study, the authors intend to analyse the socio-psychological theories of the ethnic group, ethnic identity and the relationships of ethnic identity with ethnic culture.

On the example of a comparative analysis of the characteristics of ethnic identity and its connection with ethnic culture among the residents of Eastern Latvia, the authors try to identity the common features that unite ethnic groups of the region and point to the differences in the perceptions of their ethnic identity and their manifestation among respondents. The relevance of the study is determined by the fact that changes in the social life associated with geopolitics that can create difficulties in the process of formation of ethnic identity. This case has been described in the literature when people belonging to one social community do not attribute themselves to any other ethnic group. These are residents of neighbouring territories of Belarus and Eastern Lithuania. State borders often changed here. Therefore, the residents in the documents changed their ethnicity depending on the political situation. Today they call themselves local. The residents of Belarus speak Belarusian and Polish. The residents of Lithuania speak Lithuanian and Polish. Nevertheless, they communicate with each other in their own local language, which differs from Belarusian, Polish and Russian. 


\section{Overview of the Research on Ethnic Identity Studies}

The studies carried out on ethnic identity have a focus on diverse aspects, such as a development of identity in migration (Wright, 2015), contextualization and fluidity of identity (Turner, 2004).

The most concise definition of an ethnos was given by the Russian scientist Gumilyov that is as following: ethnos is an understanding of who we are and who others are (Gumilyov, 1993). This point of view is invisibly present in theories and studies of ethnic identity. Most studies focus on the ethnic identity of a minority group, since, according to Hjort, minority cultural group display less ethnicity than minorities. The studies of ethnic identity begin with one of three starting points: the theory of social identity, according to which the simple membership of a group provides its members with a sense of belonging that promotes self-esteem, intercultural conflict, with a focus on how a minority group relates to a dominant society; identity formation that emphasizes the development and dynamic aspects of ethnic identity (Hjort, 2004). The researchers suggest several stages in the process of a formation of one's ethnic identity. The basis for this is the four-component theory of the development of personal identity by Marcia (Marcia, 1980). These are: identity diffusion, identity foreclosure, and moratorium and identity achievement. Each identity status represents a progress with regard to identity exploration and commitment to the values, beliefs, and goals that contribute to identity.

Ethnic identity is defined as a feeling of belonging to an ethnic group, also involving "thinking, perception, and behaviour and determines one's belonging to a group" (Rotheram \& Phinney, 1986, p.13). Ethnicity refers to a membership to an objective group, primarily determined by the ethnic origin of parents (Hjort, 2004). Ethnic identity defines the social boundaries and place of a person in the world. However, a social structure does not exist without culture and is filled up with the personal meaning (Gamsakhurdia, 2017). In line with the selfefficacy research, people develop prejudices about their abilities based on age, gender, ethnicity, level of education, and the socio-economic status. The first and most compelling patterns in early childhood development are gained from the parents (Swenson \& Prelow, 2005).

\section{Ethnicity and culture}

Identity develops in the context of its "ecological niche," which includes family, socioeconomic status, race, ethnicity, and culture (Swenson \& Prelow, 2005). Moreover, some researchers believe that there are minimal differences between cultural and ethnic identities (Albert, Schneeweis, \& Knobbe, 2005; Berking, 2003). 
Cultural identity includes key areas of personal identity: ideology (beliefs and values), ability to love (personal relationships), professional choice and attitude to work (Jensen, Arnett, \& McKenzie, 2011). The interconnectedness between culture and ethnic identity is described by Phinney and Ong: "Ethnic identity derives from a sense of peoplehood within a group, a culture, and a particular setting" (Phinney \& Ong, 2007, p. 271). Ethnic identity stems from a sense of nationality within a group, culture, and a specific environment.

This can be assumed that ethnic and cultural identities are interrelated as depicted in Figure 1.

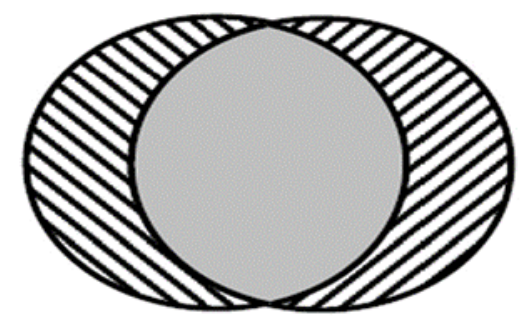

Figure 1 Schematic representation of the interrelatedness of ethnic and cultural identity

In the figure, ethnic identity is depicted by the left oval, and cultural identity by the right. There is much in common between them (gray zone), but there are also differences (shaded zones). It can be assumed that the common elements for these identities are the language and values of their ethnic culture. The hatched right area is the language and values of other ethnic cultures that have been acquired in the process of globalization. Due to this, the influence of the cultural component on the social behaviour of the individual is enhanced. This means that two or more cultures can be incorporated into one's personality in different ways, depending on the individual preferences and status or strength of different cultures that is in question. Cultural identities undertake a wide variety of forms as influenced by the global world (Jensen, Arnett, \& McKenzie, 2011). The language is a key element in the system of cultural identity with its communicative, symbolic and social functions. Therefore, the changes in language resulting from globalization and can affect the development of a person's cultural identity (Jensen, Arnett, \& McKenzie, 2011).

The process of changes of the cultural component of ethnic identity occurs as a result of the assimilation by the ethnic minority of the state (official) language of the country of residence. This process is called acculturation. Cuellar, Harris, \& Jasso's study on a cultural adaptation of Mexicans in the USA, allows one to conclude that acculturation includes five stages: Very Mexican, Mexican-Oriented Bicultural, True Bicultural, Anglo-Oriented Bicultural, and Very Anglicized. Moreover, the first generation of immigrants 
experiences the greatest difficulties with the acculturation (Cuellar, Harris, \& Jasso, 1980). To summarize the above said: there are two cultures: A and B. B is the culture of the country (it includes the language appropriate to this culture. A is the culture of the immigrant. The acculturation process in this case can be represented as such a sequence. The unconditional dominance of culture A. The dominance of culture A with the adoption of culture B. The situation of biculturalism and bilingualism. The dominance of culture $\mathrm{B}$ with the preservation of culture A. Culture B replaces culture A. The process of acculturation is associated with differences in cultures and phenotypic traits of their representatives.

As Sodowsky and Plake indicate, Africans, Asians, and South Americans in the United States are less acculturate than Europeans (Sodowsky \& Plake 1992). But, what is the content of the shaded area of ethnic identity? Researchers are looking for an answer to this question. For example, an ethnographic study in the Czech Republic revealed large differences between parents who grew up in the socialist Czech Republic and their adult children, who grew up mainly in the era of globalization (Nash, 2005). Both of them did not cease to be Czechs.

Perhaps this is the mental programming centre, about which Segers wrote (Segers, 2008). The centre of mental programming is preserved in those cases when people of the same ethnicity live in different countries and speak different languages. Therefore, sometimes linguistic identity is described within the framework of ethnic identity (Cabrera, 2013).

Globalization creates a new social and cultural reality to which a person needs to adapt. The adaptation process is associated with the revision and restructuring of one's ethnic identity. If this does not happen, fear of losing one's traditional ethnic identity may appear (Samalavičius, 2005). The reorganization of ethnic identity begins with its cultural component. According to Segers, there are three trends related to the content of cultural identity. The first trend is called globalization. In the case of globalization, the ethnic culture is subjugated to a stronger, the dominant one. The author called this process Americanization. The second tendency is localization, or the desire of an ethnic group to preserve its culture. An example is one of the most closed countries in the world - the Democratic People's Republic of Korea.

The third trend is hybridization, or the simultaneous manifestation of both trends. Moreover, the ratio of the first two trends is constantly changing. Sometimes a globalizing tendency prevails over the local one. Sometimes is the opposite. The author calls this trend "permeable isolation." An example of this phenomenoa can be found in a Japanese society (Segers, 2008). Finney suggested that members of an ethnic minority may have strong or weak 
identities with both cultures. Accordingly, four types for ethnic identity can be considered:

- integrated (strong identification with both the basic culture and its ethnic group);

- $\quad$ assimilated (strong identification with the basic culture, weak - with its own);

- $\quad$ isolated (weak identification with the basic culture, strong - with its own);

- marginal (poor identification with both basic and ethnic cultures) (Berry 1980).

\section{Research Methodology}

The authors have developed a research methodology for the study the relationship of ethnic identity and culture. Respondents were asked to name ethnic traditions, as well as literary works in which ethnic identity is most clearly manifested. Before answering the questions, each respondent provided the following information about himself/herself: father's nationality, mother's nationality, mother tongue, the knowledge of other languages, gender, age, and religious affiliation. Fifty-four respondents took part in this study. The entire sample was divided into 2 subgroups according to the language principle. The group of respondents with native Latvian language included 27 people. A group of respondents with the Russian as native language also comprised 27 people. The tables below depict the results of the study. The respondents of both groups are from the Latgale region comprising the age group from 18-59.

Research method is sufficient to explore ethnic identity since it reveals a small part from the whole design to study the ethnic identity.

\section{Research Findings}

The authors have explored the choice of literary works in which the ethnic character is the most clearly depicted by the group of respondents with Latvian as their native language).

In the section "reference of all works" in Table 1, the number of works that were mentioned, and not the total number of respondents who made a reference to these works. 
SOCIETY. INTEGRATION. EDUCATION

Proceedings of the International Scientific Conference. Volume II, May $22^{\text {th }}-23^{\text {th }}, 2020.28-40$

Table 1 The choice of literary works in which the ethnic character is most clearly depicted (a group of respondents with the Latvian as their native language)

\begin{tabular}{|c|c|c|c|c|}
\hline $\begin{array}{c}\text { The total number } \\
\text { of references to } \\
\text { all works }\end{array}$ & The title of literary work & $\begin{array}{c}\text { The } \\
\text { number of } \\
\text { references }\end{array}$ & $\begin{array}{c}\text { References from } \\
\text { another language group }\end{array}$ & $\begin{array}{c}\text { Number of } \\
\text { references }\end{array}$ \\
\hline 18 & $\begin{array}{c}\text { A. Pumpurs. Lāčplēsis } \\
\text { Bearslayer }\end{array}$ & 6 & $\begin{array}{c}\text { Dostoevsky: } \\
\text { Crime and Punishment }\end{array}$ & 1 \\
\hline- & $\begin{array}{c}\text { R. Blaumanis } \\
\text { Purva bridējs } \\
\text { In a quagmire }\end{array}$ & $\begin{array}{c}\text { Tolstoy: War and } \\
\text { Peace }\end{array}$ & 1 \\
\hline- & $\begin{array}{c}\text { J. Rainis } \\
\text { Pūt, vējini! } \\
\text { Blow, wind! }\end{array}$ & 2 & - & - \\
\hline- & $\begin{array}{c}\text { Brāli Kaudz̄̌ši Mērnieku laiki } \\
\text { Surveyors' times }\end{array}$ & 2 & - & - \\
\hline- & $\begin{array}{c}\text { A. Brigadere Sprīintis } \\
\text { Spriditis }\end{array}$ & 2 & - & - \\
\hline
\end{tabular}

Table 2 reflects the choice of literary works in which the ethnic character is the most clearly described by the group of respondents with the Russian as native language.

Table 2 The choice of literary works in which the ethnic character is the most clearly described (a group of respondents with the Russian as native language)

\begin{tabular}{|c|c|c|c|c|}
\hline $\begin{array}{c}\text { The total number } \\
\text { of references to } \\
\text { all works }\end{array}$ & The name of literary work & $\begin{array}{c}\text { The number of } \\
\text { references }\end{array}$ & $\begin{array}{c}\text { Literary works from } \\
\text { another language group }\end{array}$ & $\begin{array}{c}\text { Number of } \\
\text { references }\end{array}$ \\
\hline 33 & Tolstoy “War and Peace” & 4 & $\begin{array}{c}\text { J. Rainis } \\
\text { Golden Horse }\end{array}$ & 1 \\
\hline- & Dostoevsky' s works & 4 & $\begin{array}{c}\text { A. Grīns The Blizzard of } \\
\text { the Souls. }\end{array}$ & 1 \\
\hline- & $\begin{array}{c}\text { Pushkin “The Tale of the } \\
\text { Fisherman and the Fish” }\end{array}$ & 2 & $\begin{array}{c}\text { Brāli Kaudzīši Surveyors' } \\
\text { times }\end{array}$ & 1 \\
\hline- & - & - & Anna Brigadere Spriditis & 1 \\
\hline- & - & - & Andrejs Pumpurs \\
Bearslayer & Imants Ziedonis & 1 \\
\hline
\end{tabular}

In the first and second case, the authors reflected in the tables only those works that received two or more choices made by the respondents. This requirement did not apply to literary works from another language group. The data gained in this study indicate that that in the group of respondents with their 
Russian as native language, more literary works were mentioned that reflected the ethnic character as compared to the group of respondents with the Latvian as native language (33 versus 18). At the same time, all works that were mentioned in both groups belong to the classics or were written until the 90s of the last century. Not a single contemporary work has been mentioned. At the same time, respondents with the Latvian language as their native language have mentioned a greater number of traditions related to their ethnic mentality, than the respondents with a the Russian as their native language (35 versus 25).

The analyses of the obtained data received from the respondents with the Latvian as their native language allows concluding the following. Their answer to a question about a literary work, where the ethnic character is manifested, is dominated by the epic of Anrejs Pumpurs "Lačplēsis" (Pumpurs, 1988). As reflected by Lams, this symbol of ethnic identity was mostly manifested in this ethnic group (Lāms, 1993). In the mythology of various nations, a special place belongs to the myth of a hero, which has certain positive qualities and which needs to pass a series of tests in which these qualities are tested (Rank, 1997).

The mythological ideas from the Latvian literature about the hero are manifested in the image of Lāčplēsis. He is strong and wise, fighting the Absolute Evil (Black Knight), and is endlessly devoted to his people. The image of the hero in the Latvian epic is complemented by a female image - Laimdota. Laimdota is an ideal of a female ethnic character. She is smart, beautiful, kindhearted, feminine, faithful to Lāčplēsis and her people. Laimdota personifies the image of Latvia. This symbol of the Motherland - a woman is subsequently transformed by Rainis into the image of Baiba in the work "Breeze the Wind" ("Pūt vējiņi”) (Makarevičs, 2017). The works of Rūdolfs Blaumanis, Brāli Kaudzīši, Anna Brigadere, and Aleksandrs Green were also mentioned in the students' responses. In these works, both, male and female ethnic characters are specified, the ideal of which is reflected in the images of Lačplēsis and Laimdota.

The other work widely mentioned in students' responses was Blaumana "Purva bridejs." There are two main characters in this work: Edgars and Christina. The author depicts Edgar as a passionate but noble, corrupted but good. Christina is depicted as a good character. She is hardworking, beautiful and could be a good wife in every sense (Blaumanis, 1994). The other work that was mentioned by the students are Brāḷi Kaudzīši: "Mērnieku laiki." Here, the archetypal idea of the Motherland as a woman that contrasts masculine who is hiding under the nickname and characterizes these characters with words, jokes, jokes, and a laughter. From the beginning, Kencis leaves the impression of a very funny person. The female image of Tenis's wife, Ilze, is positive. She is hardworking, caring, intelligent, life wise, strong-willed, sensitive "Mērnieku laiki” (Kaudzītes, R., \& Kaudzītes, M., 2014). The male character Kencis is full 
of humour, self-criticism and wisdom. In Vidzeme, the ethnographic part of Latvia, where the authors of this literary work were born, Kencis often comes to the weddings and parties at the midnight. Perhaps the choice of this work by the respondents can be explained by this fact.

A. Green's work: "Blizzard of the Souls" reflects the image of the hero at the crucial moments in the history of the nation (Zaliais, 2016). The respondents recalled this work because it was recently displayed in the screens of movie theatres. Anna's Brigadere's work: "Sprīdītis" reflects the unity with nature, an understanding of natural forces, and our own wisdom that helps one to cope with life's problems and helps to achieve one's goal (Brigadere, 1998). The genre of this work is a fairy tale. It should be mentioned that the folk tales that reflect ethnic characteristics were also mentioned by the respondents from both ethnic groups: the one with the Latvian as a native language and in the group with the Russian as a native language. In this regard, it would be interesting to trace ethnic ties represented in fairy tales and in literary works.

The results obtained, the character Kencis who preserved the perception of the world as a naive child, to some extent is comparable with the image of Sprīdītis.

In the Russian speaking group of respondents, the works of Dostoevsky "Crime and Punishment" and Tolstoy's work "War and Peace" were mentioned more frequently. In these works, among the leading characters there were no representatives from the Latvian ethnic group. This is most likely that this respondent has graduated a school with the Russian language of instruction, where the main focus was placed on the study of the Russian language and literature.

The group of respondents with the Russian as their native language has named 33 works in which, to their opinion, the Russian ethnic character is manifested more vividly. These are the works of Tolstoy, Dostoevsky, and Pushkin. In Tolstoy's work "War and Peace" there are about 600 characters. The analysis of the ethnic characteristics of the character of each of them is an inextricable job. Therefore, the authors pay attention to the already mentioned works, in which the most general analysis of the Russian ethnic character is depicted.

One of these works is the article "Russian national character in the work of Leo Tolstoy: "War and Peace." The Russian character manifests itself in heroes in contact with nature, music. In his works Tolstoy shows two descriptors of the Russian character: militant and peaceful. Tolstoy does not idealize these two principles. He believes that in a human being has both, militant and a peaceful beginning. As for the female characters, Tolstoy's women and their actions rely more on emotions than on reason (Russkij nacional'nyj harakter ..., 2019). 
The given examples indicate that the ethnic character has an ideal form and many real options for his/her embodiment. In addition, this is necessary to distinguish between male and female ethnic characters. One finds several manifestations of Russian ethnic character in other literary works mentioned by the respondents. For example, the analysis of Dostoevsky's works shows that the Russian person is characterized by an indestructible thirst for truth and justice - by all means, even by making a sacrifice in the name of this sacrifice. In addition, the Russians are capable of a great feat, manifestation of selflessness and fortitude. If necessary, in exceptional cases, they are able to be united. The highest value for Dostoevsky in the Russian ethnic character was faith and suffering (Holondovich, 2015).

Pushkin's "Tale of the Fisherman and the Fish" (Pushkin, 1960) is another example of vivid ethnic features. One's hope for a miracle and hope that without any special efforts one can achieve the desired results. Pushkin's fairy tale continues the trend of Russian folk tales, where, for example, the character's desire is fulfilled by a pike, and precedes the appearance of Goncharov's work "Oblomov" (Goncharov, A., 1915). This work was mentioned by one of the respondent of a group with the Russian as a native language and serves as a vivid example of an ethnic character.

Table 3 summarizes the results of the study on ethnic traditions in which the ethnic identity of national groups is the most vividly manifested.

Table 3 The choice of folk traditions in which the ethnic character is the most clearly manifested (a group of respondents with the Latvian as a native language)

\begin{tabular}{|c|c|c|c|c|}
\hline $\begin{array}{c}\text { The total number of } \\
\text { references to all } \\
\text { ethnic traditions }\end{array}$ & National traditions & $\begin{array}{c}\text { Number of } \\
\text { references }\end{array}$ & $\begin{array}{c}\text { Tradition of other ethnic } \\
\text { group }\end{array}$ & $\begin{array}{c}\text { Number } \\
\text { of } \\
\text { references }\end{array}$ \\
\hline 35 & Midsummer celebration & 14 & $\begin{array}{c}\text { Мacленица } \\
\text { (Maslenica) }\end{array}$ & 1 \\
\hline- & $\begin{array}{c}\text { John's day (Midsummer } \\
\text { celebration) }\end{array}$ & 14 & - & - \\
\hline- & Song festival & 9 & - & - \\
\hline- & Meteni & 7 & - & - \\
\hline- & Mārtini & 6 & - & - \\
\hline- & Christmas & 6 & - & - \\
\hline- & Mik̦eli & 6 & - & - \\
\hline- & Celebration of Feasts & 4 & - & \\
\hline
\end{tabular}

In this case, we limit ourselves to the number of references equal to four, guided by the fact that the size of the scientific article has limitations. The group of respondents with the Russian as a native language is dominated by the secular traditions - the celebration of the New Year, and religious feasts - Christmas and Easter. At the same time, the traditions mentioned by the ethnic Latvians, 
reaches 27 references of the total number of references to literary works. This may indicate that there is a slow process of integration of both ethnic cultures. Among the traditions characteristic to the Russian ethnic group, the respondents referred to a number of crafts: patterned weaving, art sewing, metal forging, jewellery and wood carving.

Table 4 The choice of folk traditions in which the ethnic character is the most clearly manifested (a group of respondents with the Russian as native language)

\begin{tabular}{|c|c|c|c|c|}
\hline $\begin{array}{l}\text { The total number } \\
\text { of references to all } \\
\text { ethnic traditions }\end{array}$ & Tradition & $\begin{array}{l}\text { The number } \\
\text { of references }\end{array}$ & $\begin{array}{l}\text { Tradition celebrated by } \\
\text { the other ethnic group }\end{array}$ & $\begin{array}{l}\text { Number } \\
\text { of } \\
\text { references }\end{array}$ \\
\hline 25 & New Year & 6 & Meteņi & 1 \\
\hline- & Christmas & 5 & Mārtiņi & 1 \\
\hline- & Easter & 5 & Life cycle celebrations & 1 \\
\hline - & $\begin{array}{l}\text { Масленица } \\
\text { (Maslenitsa) }\end{array}$ & 3 & Latvian folk festivals & 1 \\
\hline- & $\begin{array}{l}\text { Иван Купала } \\
\text { (Ivan Kupala) }\end{array}$ & 3 & State holidays & 1 \\
\hline- & Midsummer celebration & 3 & - & - \\
\hline
\end{tabular}

In this sample, the number of respondents' choices was reduced to three, since the previous criterion for this case did not reflect the completeness of the picture.

\section{Conclusions}

The main conclusion that the authors may draw from the results of this study are as following: there is an ideal image of an ethnic character and many options for its embodiment in real life situations. At the same time, one must bear in mind that the ideal ethnic character has two components - masculine and feminine.

This is curious that respondents who simultaneously referred to both Latvian and Russian as their mother tongue (they were from the mixed families, three respondents in total) answered questions about literature and ethnic traditions, either as: "I don't know" or "I don't know which ethnic group I belong to".

The mentality of the respondents belonging to the group where Latvian was a native language is associated with processes in the nature. This is another confirmation that the ethnicity of the Latvian people is associated with the natural life cycle. Among the dominant traditions, they have mentioned the song and dance festival. The soul of Latvian people manifests itself in this way. The group of respondents with the Russian as their native language depict that the 
Russian character manifests itself in heroes in contact with nature, music. The Russian character is militant and peaceful. According to Tolstoy a human being has both, militant and a peaceful beginning. As for the female characters, Tolstoy's women and their actions rely more on emotions than on reason (Russkij nacional'nyj harakter ..., 2019).

\section{References}

Albert, R., Schneeweis, A., \& Knobbe, I. (2005). Strengthening, hiding or relinquishing ethnic identity in response to threat: Implications for intercultural relations. Intercultural Communication Studies, 24(1), 107-118.

Berking, H. (2003). „Ethnicity is everywhere”: On globalization and the transformation of cultural identity, Current Sociology, 51(3), 248-264.

Berry, J.W. (1980). Acculturation as varieties of adaptation In A. Padilla (Eds.). Acculturation: Theory, Models and Some New Findings. (pp.9-25). Boulder: Westview Press.

Blanton, R. (2015). Theories of Ethnicity and the Dynamics of Ethnic Change in Multiethnic Societies. Retrieved from https://doi.org/10.1073/pnas.1421406112

Blaumanis, R. (1994). Purva bridējs. In Blaumanis, R. \& Kalniņa, I. (Eds.), Kopoti Raksti (pp.353-393). Rīga: Jumava.

Brigadere, A. (1998). Sprìdītis. Rīga: Zvaigzne.

Cabrera, N. (2013). Positive Development of Minority Children. Social Policy Report, 27(2). Retrieved from https://www.srcd.org/sites/default/files/file-attachments/ spr_272_final.pdf

Cuellar, I., Harris, L.C., \& Jasso, R. (1980). An acculturation scale for Mexican American normal and clinical populations. Hispanic Journal of Behavioural Sciences, 2(3), 199217.

Gamsakhurdia, V. (2017). Quest for ethnic identity in the modern world - the Georgian case. Cogent Social Sciences, 2(1). DOI: https://doi.org/10.1080/23311886.2017.1309735.

Goncharov, A. (1915). Oblomov. London: George Allen \& UNWIN, Ltd.

Grīns, A. (2016). Dvēselı u Putenis. Rīga: Domas spēks.

Hjort, H. (2004). Ethnic Identity and Reconciliation: Two Main Tasks For the Young in Bosnia Herzegovina. Göteborg: Göteborg University.

Holondovich, E.N. (2015). Russkij harakter v rabotah F.M. Dostoevskogo. Moskva: Izd-vo «Institut psihologii RAN».

Jensen, L.A., Arnett, J.J., \& McKenzie, J. (2011). Globalization and cultural identity developments in adolescence and emerging adulthood. In S.J. Schwartz, K. Luyckx, \& V.L. Vignoles (Eds.), Handbook of Identity Theory and Research (pp.285- 301).

Kaudzītes, R., \& Kaudzītes, M. (2014). Mērnieku laiki. Rīga: Zvaigzne ABC.

Lāms, O. (1993). Latviešu Eposs: Cilme un Funkcionalitāte. Disertācijas kopsavilkums filolog̣ijas doktora grāda iegūšanai. Rīga, LU.

Makarevičs, V. (2017). Dzimtenes tēls Raina dailıradē. In M. Burima (Ed.). Aspazija-Rainis. Dzīvā dzìve. Kolektīvā Monogrāfija (pp.134 - 143). Rīga: Zinātne.

Marcia, J. (1980). Identity in adolescence. In J. Adelson (Ed.), Handbook of Adolescent Psychology (pp.159-187).

Nash, R. (2005). The economy of birth-rates in the Czech Republic. In C.B. Douglas (Ed.), Barren States: The Population "Implosion” in Europe. (pp. 93-113). New York: Berg. 
SOCIETY. INTEGRATION. EDUCATION

Proceedings of the International Scientific Conference. Volume II, May $22^{\text {th }}-23^{\text {th }}, 2020.28-40$

Phinney, J.S. (1990). Ethnic identity in adolescents and adults. Psychological Bulletin by the American Psychological Association, 108(3), 499-514.

Phinney, J.S., \& Ong, A.D. (2007). Conceptualization and measurement of ethnic identity: Current status and future directions. Journal of Counselling Psychology, 54(3), 271281.

Pumpurs, A. (1988). Lāčplēsis: Latvju Tautas Varonis. Tautas Eposs. Rīga: Zinātne.

Pushkin, A.S. (1960). Skazka o rybake i rybke. Moskva. Sovetskaja Rossija.

Rotheram, M.J., \& Phinney, J.S. (1986). Introduction: Definitions and perspectives in the study of children's ethnic socialization. In Phinney, J.S. \& Rotheram, M.J. (Eds.), Children's Ethnic Socialization: Pluralism and Development. (pp.10-28). Beverly Hills: Sage Publications.

Russkij nacional'nyj harakter v proizvedenii L. N. Tolstogo "Vojna i mir". (2019). Retrieved from www.allsoch.ru/sochineniya/7758

Samalavičius, A. (2005). National Identity, Culture and Globalization Lithuania Wakes up to a New Social and Cultural Reality. Retrieved from: https://www.eurozine.com/nationalidentity-culture-and-globalisation/

Segers, R.T. (2008). A New Japan for the Twenty-First Century. An Inside Overview of Current Fundamental Changes and Problems. Routledge: London, New York.

Sodowsky, G.R., \& Plake, B. (1992). A study of acculturation differences among international people and suggestions for sensitivity to within-group differences. Journal of Counselling and Development, 71, 53-59.

Swenson, R.R., \& Prelow, H.M. (2005). Ethnic identity, self-esteem, and perceived efficacy to psychosocial outcomes among urban adolescents. Journal of Adolescence, 28, 465477.

Turner, J.C. (2004). Fluidity in the self-concept: The shift from personal to social identity. European Journal of Social Psychology 34(3):257 - 278.

Witherspoon, D. (2013). Positive development of minority children. Social Policy Report, 27(2), 3-22.

Wright, J.D. (2015). (2 ${ }^{\text {nd }}$ Ed.). International Encyclopedia of the Social \& Behavioral Sciences. USA: University of Central Florida, Orlando. 